\title{
Determination of Chromium Species in Environmental Water and Human Serum Samples by FAAS After Magnetic Solid Phase Extraction
}

\author{
Yi-Wei Wu ${ }^{\text {a** }}$, Jing Zhang ${ }^{a}$, Jun-Feng Liu ${ }^{b}$, Zhen-Li Deng ${ }^{a}$, Mu-Xian Han ${ }^{a}$, Feng Jiang ${ }^{a}$, \\ Dai-Zhi Wang ${ }^{a}$, Hu-Kun Wang ${ }^{a}$, and Hui-Zhong Yuan ${ }^{b}$ \\ ${ }^{a}$ Department of Chemistry and Environmental Engineering, Hubei Normal University, \\ Huangshi 435002, P.R. China \\ ${ }^{b}$ Department of Clinical Laboratory, The Second Hospital of Huangshi, \\ Huangshi 435002, P.R. China
}

\section{INTRODUCTION}

Chromium is introduced into the environment (soil, surface, and groundwaters) by effluents in chemical industries and then becomes available to humans. Only trivalent and hexavalent chromium are stable enough to occur in the environment among the several chemical forms between 0 and VI. $\mathrm{Cr}(\mathrm{VI})$ is more toxic than $\mathrm{Cr}(\mathrm{III})$ and the toxic nature of the Cr(VI) ions is attributed to their high oxidation potential and their relatively small size (1). Cr(III) is considered an essential micronutrient in the human diet and is widely used as a nutritional supplement for humans and animals (2). Nevertheless, it has been demonstrated that $\mathrm{Cr}$ (III) is capable of eliciting eczema at low concentrations (3) and of causing DNA damage in cell culture systems (4). Therefore, analytical methods should be focused not only on the determination of $\mathrm{Cr}(\mathrm{VI})$ but also on the determination of $\mathrm{Cr}$ (III) (2). The development of highly sensitive analytical methodology for the detection of trace chromium species is of significant interest in analytical chemistry (5-8).

At present, several analytical techniques, including flame atomic absorption spectrometrty (FAAS) (9-11), spectrophotometry $(12,13)$, stripping voltammetry (SV) (14-16), inductively coupled plasma optical emission spectrometry (ICP-OES) $(17,18)$, and inductively coupled

\footnotetext{
*Corresponding author.

E-mail: chemwuyiwei@tom.com

Tel.: +867146515602

Fax: +867146573832
}

\section{ABSTRACT}

Silica-coated $\mathrm{Fe}_{3} \mathrm{O}_{4}$ magnetic nanoparticles (SCMNPs) modified with N-(2-aminoethyl)-3-aminopropyltrimethoxy-silane (AEAPS) (AEAPS-SCMNPs) were prepared and employed as magnetic solid phase extraction (MSPE) adsorbent for differentiation between $\mathrm{Cr}(\mathrm{III})$ and $\mathrm{Cr}(\mathrm{VI})$ in environmental water and human serum samples. At pH 5.0-9.0, AEAPSSCMNPs were selective towards Cr(III) but hardly Cr(VI).

The retained Cr(III) was subsequently eluted with $1.0 \mathrm{~mL}$ of $1.0 \mathrm{~mol} \mathrm{~L}^{-1} \mathrm{HNO}_{3}$ followed by magnetic decantation. Total chromium was determined after reduction of $\mathrm{Cr}(\mathrm{VI})$ to $\mathrm{Cr}$ (III) by ascorbic acid. A speciation procedure for chromium in environmental water and human serum samples by AEAPS-SCMNPs-MSPE prior to FAAS analysis was developed. Various parameters affecting AEAPS-SCMNPs-MSPE were optimized systematically.

Under the optimum conditions, the adsorption capacity of AEAPS-SCMNPs for Cr(III) was $22.6 \mathrm{mg} \mathrm{g}^{-1}$. With an enrichment factor of 100 , a detection limit of $0.66 \mathrm{ng} \mathrm{mL}^{-1} \mathrm{Cr}$ (III) was obtained, and the proposed method was successfully applied for the speciation of chromium in environmental water and human serum samples with satisfactory results.

plasma mass spectrometry (ICP-MS) $(19,20)$, have been applied to accurately determine trace chromium and its species in various samples. However, an effective separation and preconcentration procedure, such as concentration and purification of and differentiation between Cr(III) and Cr(VI), has to be carried out prior to analysis because of the extremely low concentrations in real samples and due to severe matrix interference.

The most widely used techniques for separation and preconcentration of chromium include cloud point extraction (CPE) $(21,22)$, membrane extraction $(23,24)$, dispersive liquid-liquid microextraction (DLLME) (25), solid phase extraction (SPE) $(26,27)$, coprecipitation $(28,29)$, and ion-exchange separation $(30,31)$. Currently, SPE is one of the most commonly techniques used for the separation and preconcentration of analytes in actual samples due to its advantages of a high enrichment factor (EF), rapid phase separation, low consumption of organic solvents, and the ability of combining with different detection techniques in the form of on-line or off-line mode (26). In the SPE procedure, selecting an appropriate sorbent is an important strategy for improving the analytical procedure.

There are many sorbents used in SPE for the separation and preconcentration of metal ions (32-34). Nano-sized carriers have attracted substantial interest in the scientific community and developed rapidly over the past decade as a result of the high specific surface areas, highly active surface sites, and the absence of internal diffusion resistance in the separation process, (5). Magnetic nanoparticles (35-38), as a new kind of nanometer material, 
are widely used in the fields of mechanical, optical, chemical, and electronic properties of materials on the nanoscale and play a critical role in nanotechnology, biology, and medicine. Because they are superparamagnetic, a magnetic separation mode can be quickly and conveniently carried out under an extra magnetic field when they are used as the solid phase extraction sorbents. With the motivation of understanding the novel properties and superparamagnetism of magnetic nanoparticles, much effort has been devoted to the development of new magnetic nanoparticles in magnetic solid phase extraction (MSPE) $(5,34)$. It should be stressed, however, that pure inorganic magnetic particles as adsorption materials (such as $\mathrm{Fe}_{3} \mathrm{O}_{4}$ and $\mathrm{Fe}_{2} \mathrm{O}_{3}$ ) are prone to forming a large aggregation, they are difficult to operate, and their magnetic properties are also changed. Moreover, these nanometer metal oxides are not target-selective and are unsuitable for actual samples with complicated matrices. Fortunately, the pure inorganic magnetic particles can be modified in different ways to change their extraction properties (36). Therefore, a suitable coating of these magnetic nanoparticles to prevent such limitations from occurring has been proven to be one of the most efficient ways $(37,38)$.

In the present work, silicacoated $\mathrm{Fe}_{3} \mathrm{O}_{4}$ magnetic nanoparticles (SCMNPs), modified with N-(2-aminoethyl)-3-aminopropyltrimethoxy-silane (AEAPS) (AEAPS-SCMNPs), were prepared and employed as a MSPE sorbent for the speciation of trace Cr(III) and $\mathrm{Cr}(\mathrm{VI})$ in environmental water and human serum samples.

\section{EXPERIMENTAL}

\section{Instrumentation}

A Model AA-6200 atomic absorption spectrometer (Shimadzu,
Japan) using an air-acetylene flame was employed for the determination of the target element. The operating conditions for FAAS are listed in Table I. The reported $\mathrm{pH}$ of the solution was carefully measured with a PHS-3C pH-meter (Shanghai Precision \& Scientific Instrumental Co., Ltd, Shanghai, P.R. China). An ultrasonicator (Kedao Instrument Co., Ltd., Shanghai, P.R. China) was used to disperse the nanoparticles in solution. The AEAPS-SCMNPs were characterized by a Tecnai $G^{2} 20$ S-TWIN FEI transmission electronic microscope (Tecnai, Czechoslovakia). A zeta-Meter4.0+ zeta potential instrument (Ankersmid, Holland) was used to determine the zeta potential of the AEAPS-SCMNPs. All instrumental parameters were used as recommended by the manufacturers.

\section{Standard Solution and Reagents}

Stock solutions ( $\left.1 \mathrm{~g} \mathrm{~L}^{-1}\right)$ of $\mathrm{Cr}$ (III) and $\mathrm{Cr}(\mathrm{VI})$ were prepared from high-purity $\mathrm{CrCl}_{3} \cdot 6 \mathrm{H}_{2} \mathrm{O}$ and $\mathrm{K}_{2} \mathrm{Cr}_{2} \mathrm{O}_{7}$ (The First Reagent Factory, Shanghai, P.R. China), respectively. The amino-silane coupling agent, $\mathrm{N}$-(2-aminoethyl)-3-aminopropyltrimethoxysilane (AEAPS), was obtained from Hubei Wuhan University Silicone New Material Co., Ltd. The sizes of high purity $\mathrm{Fe}_{3} \mathrm{O}_{4}$ nanoparticles (Shanghai Jingchun Reagent Co. Ltd., P.R. China) are about $20 \mathrm{~nm}$. A 10.0\% (m/v) aqueous ascorbic acid solution was prepared fresh daily. Britton-Robinson

\section{TABLE I}

Model AA-6200 AAS Operating Conditions

\begin{tabular}{lr}
\hline \multicolumn{2}{c}{ Parameters } \\
\hline Wavelength & \multicolumn{1}{c}{ Cr: $357.9 \mathrm{~nm}$} \\
Flame Type & Air-acetylene flame \\
Ratio of Air to Acetylene & $8: 2.8$ \\
HCL Current & $10 \mathrm{mV}$ \\
Slit Width & $0.2 \mathrm{~nm}$ \\
Observation Height & $7 \mathrm{~mm}$ \\
\hline
\end{tabular}

(B-R) buffer solution, composed of an appropriate volume of $0.04 \mathrm{~mol} \mathrm{~L}^{-1}$ each of $\mathrm{H}_{3} \mathrm{PO}_{4}, \mathrm{HAc}$, and $\mathrm{H}_{3} \mathrm{BO}_{3}$ and $0.2 \mathrm{~mol} \mathrm{~L}^{-1} \mathrm{NaOH}$, was used to adjust the $\mathrm{pH}$ of the sample solution. All other chemicals (The First Reagent Factory, Shanghai, P.R. China) were of analytical grade. Doubly distilled water (DDW) was used throughout.

\section{Preparation of AEAPS-SCMNPs}

\section{Preparation of SCMNPS}

The preparation method is similar to previous protocols reported by Liu et al. (39). After dissolving $47.50 \mathrm{~g}$ of sodium silicate in DDW, the $\mathrm{pH}$ of the solution was buffered to $12.0 \sim 13.0$ by dropwise introduction of hydrochloric acid. The sodium silicate solution and $10.0 \mathrm{~g}$ $\mathrm{Fe}_{3} \mathrm{O}_{4}$ nanoparticles were poured into a $2 \mathrm{~L}$ beaker equipped with a mechanical stirrer. After stirring for 30 minutes, the temperature of the mixture was increased to $80^{\circ} \mathrm{C}$. Subsequently, the $\mathrm{pH}$ was adjusted to $6.0 \sim 7.0$ by dropwise addition of hydrochloric acid. The resulting SCMNPs were washed several times with DDW by magnetic decantation. The procedure was repeated three times to ensure sufficient amount of silica coating on $\mathrm{Fe}_{3} \mathrm{O}_{4}$ nanoparticles. Finally, the SCMNPs were dispersed in $250 \mathrm{~mL}$ methanol.

\section{SCMNPs Modified by AEAPS}

A 25.0-mL SCMNPs mixture was diluted to $150.0 \mathrm{~mL}$ with methanol, mixed with $150 \mathrm{~mL}$ glycerol, ultrasonicated for 30 minutes, transferred to a 500-mL 3-necked flask equipped with a stirrer, followed by addition of $10.0 \mathrm{~mL}$ of AEAPS. The temperature of the mixture was increased to $80 \sim 90^{\circ} \mathrm{C}$ under rapid stirring for 3 hours. The resulting nanoparticles were washed three times with DDW, then twice with methanol, dried into powder form at room temperature under vacuum. Then $100.0 \mathrm{mg}$ of nanoparticles were immersed in $5.0 \%(\mathrm{v} / \mathrm{v})$ glutaraldehyde solution with $0.1 \mathrm{~mol} / \mathrm{L}$ phosphate buffer 
solution ( $\mathrm{pH} 7.4)$ for 6 hours at room temperature, subsequently washed with DDW, and finally dried into powder form at room temperature under vacuum, then stored for later use.

\section{General AEAPS-SCMNPs MSPE Procedure}

The AEAPS-SCMNPs MSPE procedure was performed as follows: A portion of the sample solution containing the target ions was transferred to a $25.0-\mathrm{mL}$ beaker, the $\mathrm{pH}$ value was adjusted to 5.5 with a $\mathrm{B}-\mathrm{R}$ buffer solution, and the final volume was diluted to $10.0 \mathrm{~mL}$ with DDW. Then, $50.0 \mathrm{mg}$ of AEAPS-SCMNPs was added, and the mixture ultrasonicated for 15 minutes to facilitate adsorption of the target ions onto the AEAPS-SCMNPs. Subsequently, the magnetic adsorbent was separated easily and quickly with a magnet and the supernatants were decanted directly. After removing the magnet, $1.0 \mathrm{~mL}$ of $1.0 \mathrm{~mol} \mathrm{~L}^{-1} \mathrm{HNO}_{3}$ was added as eluent and ultrasonicated again for 5 minutes. Then the magnet was used again to settle the magnetic nanoparticles and the eluate was pipetted into a test tube for subsequent FAAS analysis.

\section{Sample Pretreatment}

Water samples collected from two natural lakes (Qingshan Lake and Sanjiao Lake, Huangshi, P.R. China) were filtered through a 0.45- $\mu \mathrm{m}$ membrane filter (Shanghai Xingya Purifying Materials Factory). The filtrates were collected and stored at $4^{\circ} \mathrm{C}$ in a polyethylene containers for subsequent use.

Human serum samples, obtained randomly at the Department of Clinical Laboratory, the Second Hospital, Huangshi, P.R. China, were stored at $4^{\circ} \mathrm{C}$ in polyethylene containers for subsequent use.

\section{RESULTS AND DISCUSSION}

\section{Particle Morphologies of AEAPS-SCMNPS}

The adsorption characteristics of a material are related to its physical morphology. The morphologies of AEAPS-SCMNPs, characterized by transmission electronic microscopy, showed that the size of the AEAPS-SCMNPs was about $50 \mathrm{~nm}$, indicating that it is a nano-sized material and thus offers fairly good performance with MSPE.

\section{Effect of pH on Adsorption of Cr(III) and Cr(VI)}

The adsorptive rates of $\mathrm{Cr}$ (III) and $\mathrm{Cr}(\mathrm{VI})$ on AEAPS-SCMNPs were investigated at the $\mathrm{pH}$ level ranging from 2.0 to 9.0 in a B-R buffer solution. The results in Figure 1 show that AEAPS-SCMNPs have different adsorption characteristics towards $\mathrm{Cr}$ (III) and $\mathrm{Cr}(\mathrm{VI})$ depending on the $\mathrm{pH}$ range. The adsorptive rates of $\mathrm{Cr}$ (III) increase with $\mathrm{pH}$, then attain a quantitative platform at $\mathrm{pH}$ 5.0-9.0. However, Cr(VI) almost cannot be adsorbed by AEAPS-SCMNPs under this $\mathrm{pH}$ range. It is clear, therefore, that AEAPS-SCMNPs are selective towards Cr(III) but hardly to $\mathrm{Cr}(\mathrm{VI})$ in the $\mathrm{pH}$ range of 5.0 9.0. Therefore, a $\mathrm{pH}$ of 5.5 was selected for subsequent work.

To investigate the adsorptive mechanism of AEAPS-SCMNPs for $\mathrm{Cr}(\mathrm{III})$ and $\mathrm{Cr}(\mathrm{VI})$, the zeta potential of AEAPS-SCMNPs was measured at $\mathrm{pH}$ 4.0 9.0, and the results are listed in Table II. The data tell us that the surface charges of AEAPS-SCMNPs are negative at $\mathrm{pH} 5.0 \sim 9.0$ and positive at $\mathrm{pH} 4$.0.

Figure 2 shows the chemical species of chromium as a function of $\mathrm{pH}$ and potential. As can be seen, trivalent chromium tends to form cation $\left(\mathrm{Cr}(\mathrm{OH})^{2+}, \mathrm{Cr}(\mathrm{OH})_{2}{ }^{+}\right)$ or electrically neutral products $\left(\mathrm{Cr}(\mathrm{OH})_{3}\right)$ at $\mathrm{pH}$ 5.0 9.0, while hexavalent chromium usually exists

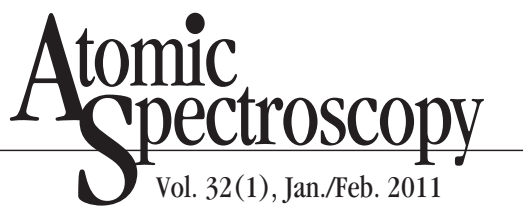

as anions of $\mathrm{HCrO}_{4}^{-}, \mathrm{Cr}_{2} \mathrm{O}_{7}$, and $\mathrm{CrO}_{4}$ under this $\mathrm{pH}$ range. This means that AEAPS-SCMNPs repel $\mathrm{Cr}(\mathrm{VI})$ and magnetize $\mathrm{Cr}$ (III) at $\mathrm{pH}$ 5.0 9.0, and thus Cr(III) is likely to be adsorbed by AEAPS-SCMNPs.

\section{Effect of Elution Condition}

With respect to stripping of Cr(III) from AEAPS-SCMNPs, the possible elution solvents selected and examined were $\mathrm{HNO}_{3}, \mathrm{HCl}$, thiourea in $0.1 \mathrm{~mol} \mathrm{~L}^{-1} \mathrm{HCl}$, and EDTA. The results in Figure 3 show that only $\mathrm{HNO}_{3}$ has the best elution effect. Thus, $\mathrm{HNO}_{3}$ was adopted as the eluent, and different concentrations of $\mathrm{HNO}_{3}$ ranging from 0.5 to $2.5 \mathrm{~mol} \mathrm{~L}^{-1}$ were investigated. It was found that quantitative recovery for $\mathrm{Cr}$ (III) could be obtained with $1.0 \sim 2.5 \mathrm{~mol} \mathrm{~L}^{-1} \mathrm{HNO}_{3}$. For this work, $1.0 \mathrm{~mol} \mathrm{~L}^{-1} \mathrm{HNO}_{3}$ was selected for further experiments.

The effect of $\mathrm{HNO}_{3}$ volume on the recovery of $\mathrm{Cr}$ (III) was also studied by keeping its concentration at $1.0 \mathrm{~mol} \mathrm{~L}^{-1}$. It was found that quantitative recoveries of $>90 \%$ were obtained with $1.0 \mathrm{~mL}$ of $1.0 \mathrm{~mol} \mathrm{~L}^{-1} \mathrm{HNO}_{3}$. Therefore, a volume of $1.0 \mathrm{~mL}$ of eluent was used for this study.

\section{Effect of Sample Volume}

In order to explore the possibility of enriching low concentrations of the analyte from a large sample volume, the maximum applicable volume must be determined. For this purpose, 10.0, 15.0, 25.0, 50.0, $75.0,100.0$, and $150.0 \mathrm{~mL}$ of sample volume, fixing $\mathrm{Cr}$ (III) at $2.0 \mu \mathrm{g}$, were operated according to the general procedure. The results indicated that quantitative recoveries of over $90 \%$ for Cr(III) were obtained with a sample volume of less than $150.0 \mathrm{~mL}$.

As described previously, $1.0 \mathrm{~mL}$ of $1.0 \mathrm{~mol} \mathrm{~L}^{-1} \mathrm{HNO}_{3}$ is enough to elute the analyte adsorbed on AEAPS-SCMNPs. An enrichment factor of 100 was obtained with 


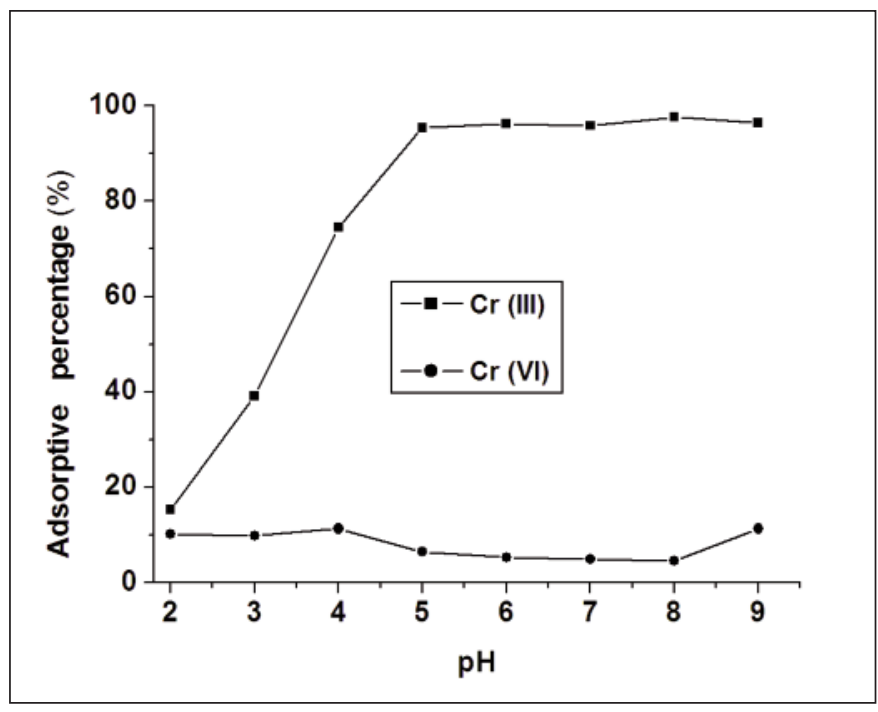

Fig. 1. Effect of $\mathrm{pH}$ on the adsorption percentage of $\mathrm{Cr}$ (III) and Cr (VI) on AEAPS-SCMNPs. Cr(III) and Cr (VI): $0.5 \mathrm{mg} \mathrm{L}^{-1}$.

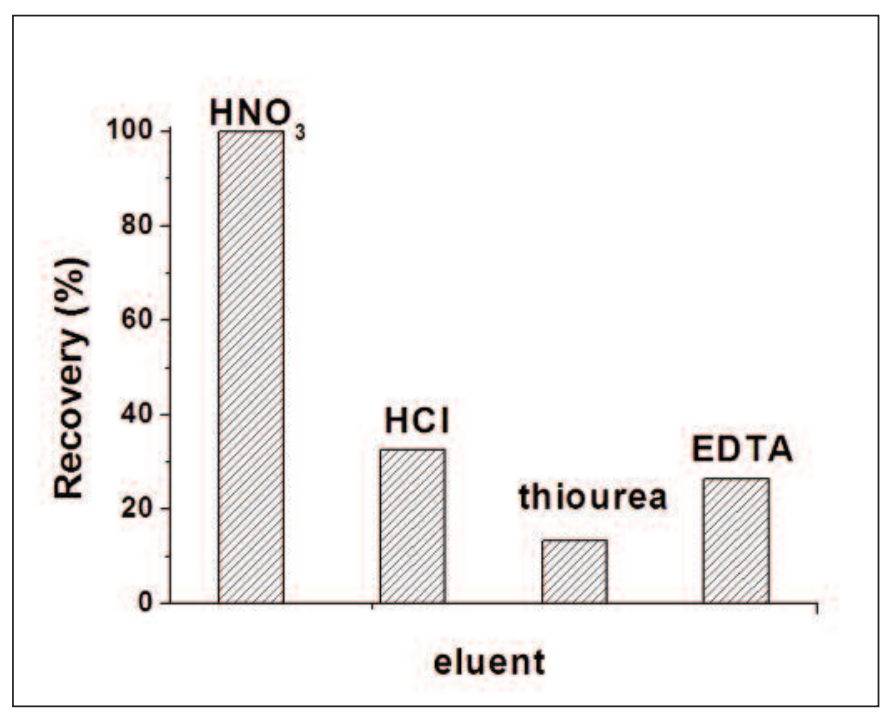

Fig. 3. Effect of various eluents on the recovery of Cr(III) on AEAPS-SCMNPS

$\mathrm{Cr}(\mathrm{III}): 0.5 \mathrm{mg} \mathrm{L}^{-1}, \mathrm{HNO}_{3}: 1.0 \mathrm{~mol} \mathrm{~L} \mathrm{~L}^{-1} \mathrm{HCl}: 2.0 \mathrm{~mol} \mathrm{~L} \mathrm{~L}^{-1}$, thiourea in $0.1 \mathrm{~mol} \mathrm{~L}^{-1} \mathrm{HCl}$ : $60 \mathrm{~g} \mathrm{~L} \mathrm{~L}^{-1}$, EDTA : $0.02 \mathrm{~mol} \mathrm{~L}^{-1}$.

TABLE II

Results of Zeta Potential of AEAPS-SCMNPs at Varying pH

\begin{tabular}{lccccccc}
\hline $\mathrm{pH}$ & 4 & 5 & 6 & 7 & 8 & 9 & 9.3 \\
\hline Zeta Potential (mV) & 4.45 & -7.87 & -30.2 & -25.98 & -18.64 & -18.04 & -20.02 \\
\hline
\end{tabular}

$100.0 \mathrm{~mL}$ of sample solution which provides the feasibility of analyzing samples with different analyte concentration levels.

\section{Effect of Ultrasonic Time}

In order to minimize the time required for MSPE, different times for adsorption (5, 10, 15, 20 minutes) and for elution $(2,5,8,10$, 12 minutes) were investigated. The results revealed that for the quantitative recovery of Cr(III), sorption of over $95 \%$ was achieved when the ultrasonication time was greater than 15 minutes for adsorption and greater than 5 minutes for elution. Therefore, 15 minutes was used for adsorption and 5 minutes for elution in subsequent experiments.

\section{Effect of Sediment Time}

Conventional static solid phase extraction (SPE) usually requires filtration or centrifugation to separate the adsorbent from aqueous solutions, which makes the method complex and time-consuming. However, with the MSPE procedure, the adsorbent separates rapidly from the sample solution using an external magnetic field which is due to the superparamagnetism of 
the nanoparticles. The effect of sediment time on the recovery of Cr(III) was investigated. No significant effect was observed when the sedimentation time was greater than 2.5 minutes. Therefore, a sediment time of 3.0 minutes was selected for this work.

\section{Effect of Coexisting Ions}

The effects of common coexisting ions on the adsorption of Cr(III) on AEAPS-SCMNPs were investigated under the optimum conditions. In these experiments, the target analyte solutions containing the added other ions were treated according to the recommended procedure. The effect is expressed as the recovery in the presence of interfering ions relative to the interference-free response. The results showed that the recoveries of Cr(III) remained above $90 \%$ even in the presence of the following ions: $5.0 \mathrm{mg} \mathrm{mL}^{-1} \mathrm{~K}^{+} ; 3.0 \mathrm{mg} \mathrm{mL}^{-1} \mathrm{Na}^{+}$; $120.0 \mu \mathrm{g} \mathrm{mL}^{-1} \mathrm{Mg}^{2+} ; 80.0 \mu \mathrm{g} \mathrm{mL}^{-1}$ $\mathrm{Ca}^{2+} ; 50.0 \mu \mathrm{g} \mathrm{mL}^{-1} \mathrm{Al}^{3+}, \mathrm{Pb}^{2+}$, and $\mathrm{Zn}^{2+} ; 10.0 \mu \mathrm{g} \mathrm{mL} \mathrm{m}^{-1} \mathrm{Mn}^{2+} ; 5.0 \mu \mathrm{g} \mathrm{mL}^{-1}$ $\mathrm{Cu}^{2+} ; 0.8 \mu \mathrm{g} \mathrm{mL}^{-1} \mathrm{Hg}^{2+} ; 4.5 \mathrm{mg} \mathrm{mL}^{-1}$ $\mathrm{Cl}^{-} ; 4.1 \mathrm{mg} \mathrm{mL}^{-1} \mathrm{PO}_{4}{ }^{3-}$; and $267.0 \mu \mathrm{g} \mathrm{mL}^{-1} \mathrm{SO}_{4}{ }^{2-}$. This indicates that the method has good tolerance to matrix interference with a potential to be applied to analyze real samples.

\section{Adsorption Capacity}

The adsorption capacity of AEAPS-SCMNPs is an important factor because it will reflect how much AEAPS-SCMNPs is required to quantitatively concentrate the analyte from a given solution. To test the adsorption capacity of AEAPS-SCMNPs, $50.0 \mathrm{mg}$ of AEAPS-SCMNPs was added into $10.0 \mathrm{~mL}$ of various concentrations of Cr(III) standard solution (20.0, 50.0, 100.0, 150.0, 200.0 $\left.\mathrm{mg} \mathrm{L}^{-1}\right)$. The results showed that the static adsorption capacity of $\mathrm{Cr}$ (III) was $22.6 \mathrm{mg} \mathrm{g}^{-1}$ which is higher than other magnetic nanoparticles $(5,34)$.

\section{Analytical Performance}

Under the optimum conditions, the detection limit (evaluated as the concentration corresponding to three times the standard deviation of 9 runs of the blank solution) of this method for Cr(III) with an enrichment factor of 100 was $0.66 \mathrm{ng} \mathrm{mL}^{-1}$, and the relative standard deviation (RSD) was $2.1 \%$ ( $\left.\mathrm{n}=11, \mathrm{c}=20 \mathrm{ng} \mathrm{mL} \mathrm{m}^{-1}\right)$. A comparison of the limit of detection (LOD) obtained by this method with that obtained by several other approaches for speciation of $\mathrm{Cr}$ (III) or $\mathrm{Cr}(\mathrm{VI})$ is shown in Table III. As can be seen, the LOD obtained by this method is superior to other methods $(40,42)$.

\section{Analytical Application}

To verify the validity of the developed method, it was applied to the determination of total chromium in certified reference material GBW07605 Tea Leaves (obtained from Geophysical and Geochemical Prospecting, Langfang, P.R. China). A $0.1 \mathrm{~g}$ amount was weighed and dissolved in $10.0 \mathrm{~mL}$ of $\mathrm{HNO}_{3}-\mathrm{HClO}_{4}(4: 2, \mathrm{v} / \mathrm{v})$ on a hot plate under mild heating, then vaporized to near dryness, and dissolved in $10.0 \mathrm{~mL}$ of $\mathrm{pH} 5.5 \mathrm{~B}-\mathrm{R}$ buffer solution containing $1.0 \mathrm{~mL}$ of $10 \%(\mathrm{~m} / \mathrm{v})$ aqueous ascorbic acid solution to reduce $\mathrm{Cr}(\mathrm{VI})$ to $\mathrm{Cr}(\mathrm{III})$. The total chromium concentration was determined according to the recommended procedure. The determined value obtained by this method $\left(0.79 \pm 0.01 \mu \mathrm{g} \mathrm{g}^{-1}\right)$ was in good agreement with the certified value $\left(0.80 \pm 0.02 \mu \mathrm{g} \mathrm{g}^{-1}\right)$.

The proposed method was applied to the determination of Cr(III) and Cr(VI) in environmental water $(15.0 \mathrm{~mL}$ of the filtrates of water was diluted to $25.0 \mathrm{~mL}$ with B-R buffer solutions at $\mathrm{pH}$ 5.5) and human serum samples $(0.5 \mathrm{~mL}$ of the human serum was directly diluted to $5.0 \mathrm{~mL}$ with the same buffer solutions). The analytical results obtained by FAAS are given in Tables IV and V. As can be seen, the species of chromium in human serum are primarily $\mathrm{Cr}$ (III); no Cr(VI) species were detected. However, in environmental water, both $\mathrm{Cr}(\mathrm{III})$ and $\mathrm{Cr}(\mathrm{VI})$ species were found. Moreover, the results show that the concentrations of $\mathrm{Cr}$ (III) in patient with Type 2 Diabetes Mellitus are lower than those in healthy persons. This conforms to the reports that plasma chromium concentrations are inversely correlated with plasma glucose and that Type 2 diabetes patients have high levels of urinary chromium leading to increased loss of chromium $(44,45)$. Tables IV and V also list the recoveries for the spiked environmental water and human serum samples and fairly good recoveries for the two chromium species were obtained.

\section{CONCLUSION}

New magnetic nanoparticles, silica-coated $\mathrm{Fe}_{3} \mathrm{O}_{4}$ magnetic nanoparticles (SCMNPs), modified with N-(2-aminoethyl)-3-aminopropylrimethoxy-silane (AEAPS), have been prepared and used to separate/preconcentrate chromium species in environmental water samples. The magnetic solid phase extraction (MSPE) behavior and mechanism of $\mathrm{Cr}$ (III) and $\mathrm{Cr}(\mathrm{VI})$ on AEAPS-SCMNPs have been investigated in detail. A simple, selective, sensitive, and accurate MSPE-FAAS method, resulting in a 100 -fold enhancement in sensitivity, has been established for the separation and determination of chromium species in environmental water and human serum samples with satisfactory results. 
TABLE III

Figures of Merit of Methods for Speciation of Cr(III) and Cr(VI)

\begin{tabular}{|c|c|c|c|c|}
\hline Matrix & $\begin{array}{l}\text { Preconcentration Technique and Enrichment } \\
\text { Factor (EF) }\end{array}$ & LOD & $\begin{array}{l}\text { Detection } \\
\text { Technique }\end{array}$ & Ref. \\
\hline Lake water and & MSPE (AEAPS-SCMNPs) & $0.66 \mu \mathrm{g} \mathrm{L}-1$ for $\mathrm{Cr}(\mathrm{III})$ & FAAS & This \\
\hline Pool water & $\mathrm{EF}: 100$ for $\mathrm{Cr}(\mathrm{III})$ & & & work \\
\hline \multirow{2}{*}{$\begin{array}{l}\text { Lake water and } \\
\text { tap water }\end{array}$} & SPE (CCBFeCNP) & \multirow[t]{2}{*}{$52.4 \mathrm{ng} \mathrm{L}-1$ for $\mathrm{Cr}(\mathrm{III})$} & \multirow[t]{2}{*}{ FAAS } & \multirow[t]{2}{*}{5} \\
\hline & EF: 100 for $\mathrm{Cr}(\mathrm{III})$ & & & \\
\hline Natural water & $\begin{array}{l}\text { Coprecipitation of Cr(III) on EPHBAT } \\
\text { without carrier element EF: } 50 \text { for } \mathrm{Cr} \text { (III) }\end{array}$ & $1.00 \mu \mathrm{g} \mathrm{L}-1$ for $\mathrm{Cr}(\mathrm{III})$ & FAAS & 40 \\
\hline \multirow[t]{2}{*}{ Tap water } & \multirow[t]{2}{*}{ coprecipitation EF: 100 for $\mathrm{Cr}(\mathrm{III})$} & $0.65 \mu \mathrm{g} \mathrm{L}-1$ for $\mathrm{Cr}(\mathrm{III})$ & \multirow[t]{2}{*}{ AAS } & \multirow[t]{2}{*}{41} \\
\hline & & $0.78 \mu \mathrm{g} \mathrm{L}-1$ for $\mathrm{Cr}(\mathrm{VI})$ & & \\
\hline \multirow[t]{2}{*}{ Sediment } & \multirow{2}{*}{$\begin{array}{l}\text { Cloud point extraction EF: } 45 \text { for } \mathrm{Cr}(\mathrm{III}) \\
\text { and } 40 \text { for } \mathrm{Cr}(\mathrm{VI}) \text {. }\end{array}$} & $7.50 \mu \mathrm{g}$ L-1 for $\mathrm{Cr}(\mathrm{III})$ & \multirow[t]{2}{*}{ HPLC } & \multirow[t]{2}{*}{42} \\
\hline & & $3.50 \mu \mathrm{g} \mathrm{L}-1$ for $\mathrm{Cr}(\mathrm{VI})$ & & \\
\hline \multirow{2}{*}{$\begin{array}{l}\text { Lake water and } \\
\text { tap water }\end{array}$} & Ultrasonic probe-assisted ionic liquid dispersive & $0.07 \mu \mathrm{g} \mathrm{L}-1$ for $\mathrm{Cr}(\mathrm{VI})$ & \multirow[t]{2}{*}{ ETAAS } & \multirow[t]{2}{*}{43} \\
\hline & $\begin{array}{l}\text { liquid-liquid microextraction } \\
\mathrm{EF}: 300 \text { for } \mathrm{Cr}(\mathrm{VI})\end{array}$ & & & \\
\hline
\end{tabular}

TABLE IV

Determination of Cr(III) and Cr(VI) in Environmental Water (ng mL $\left.\mathbf{~}^{-1}\right)$

\begin{tabular}{|c|c|c|c|c|c|c|c|}
\hline \multirow[t]{2}{*}{ Samples } & \multicolumn{2}{|c|}{ Added } & \multicolumn{3}{|c|}{ Found $^{\mathrm{a}}$} & \multicolumn{2}{|c|}{ Recovery (\%) } \\
\hline & Cr(III) & $\mathrm{Cr}(\mathrm{VI})$ & $\mathrm{Cr}(\mathrm{III})$ & $\mathrm{Cr}(\mathrm{VI})^{\mathrm{b}}$ & Total & $\mathrm{Cr}(\mathrm{III})$ & $\mathrm{Cr}(\mathrm{VI})$ \\
\hline \multirow[t]{3}{*}{ Water $1^{c}$} & 0 & 0 & $6.5 \pm 0.3$ & $3.9 \pm 0.1$ & $10.4 \pm 0.3$ & & \\
\hline & 4 & 4 & $10.3 \pm 0.4$ & $8.0 \pm 0.3$ & $18.7 \pm 0.5$ & 95.0 & 102.5 \\
\hline & 8 & 8 & $14.5 \pm 0.5$ & $11.8 \pm 0.7$ & $26.2 \pm 0.6$ & 100.0 & 98.8 \\
\hline \multirow[t]{3}{*}{ Water $2^{\mathrm{d}}$} & 0 & 0 & $2.6 \pm 0.2$ & $0.8 \pm 0.03$ & $3.4 \pm 0.2$ & & \\
\hline & 4 & 4 & $6.5 \pm 0.3$ & $4.5 \pm 0.2$ & $11.2 \pm 0.3$ & 97.5 & 92.5 \\
\hline & 8 & 8 & $10.3 \pm 0.5$ & $8.9 \pm 0.4$ & $19.5 \pm 0.6$ & 96.2 & 101.2 \\
\hline
\end{tabular}

${ }^{\mathrm{a}}$ Mean \pm average deviation, $\mathrm{n}=5 ;{ }^{\mathrm{b}}$ Calculated value; ${ }^{\mathrm{c}}$ Qingshan Lake; ${ }^{\mathrm{d}}$ Sanjiao Lake.

TABLE V

Determination of Cr(III) and Cr(VI) in Human Serum Samples (mg L $\left.{ }^{-1}\right)$

\begin{tabular}{|c|c|c|c|c|c|c|c|}
\hline \multirow[t]{2}{*}{ Samples } & \multicolumn{2}{|c|}{ Added } & \multicolumn{3}{|c|}{ Found $^{\mathrm{a}}$} & \multicolumn{2}{|c|}{ Recovery (\%) } \\
\hline & $\mathrm{Cr}(\mathrm{III})$ & $\mathrm{Cr}(\mathrm{VI})$ & $\mathrm{Cr}(\mathrm{III})$ & $\mathrm{Cr}(\mathrm{VI})^{\mathrm{b}}$ & Total & $\mathrm{Cr}(\mathrm{III})$ & $\mathrm{Cr}(\mathrm{VI})$ \\
\hline \multirow[t]{2}{*}{ Human serum $1^{\mathrm{c}}$} & 0 & 0 & $0.26 \pm 0.2$ & - & $0.24 \pm 0.3$ & & \\
\hline & 2 & 2 & $2.25 \pm 0.3$ & $2.01 \pm 0.2$ & $4.21 \pm 0.2$ & 99.5 & 100.5 \\
\hline Human serum $2^{\mathrm{d}}$ & 0 & 0 & $0.89 \pm 0.2$ & - & $0.88 \pm 0.2$ & & \\
\hline
\end{tabular}

${ }^{\mathrm{a}}$ Mean \pm average deviation, $\mathrm{n}=5 ;{ }^{\mathrm{b}}$ Calculated value; ${ }^{\mathrm{c}}$ Patient with Type 2 Diabetes Mellitus; ${ }^{\mathrm{d}}$ Healthy person.

- : not detected. 


\section{ACKNOWLEDGMENTS}

This project was financially supported by National Nature Science Foundation of China (No. 20975031), Education Committee of Hubei Province (Q20102506), Key Laboratory of Analytical Chemistry for Biology and Medicine (Wuhan University), Ministry of Education (ACBM2010004), Young and Middle-Aged Elitists' Scientific and Technological Innovation Team Project of Hubei Education Department of China under Grant (T201007).

Received August 26, 2010

\section{REFERENCES}

1. S.S. Wise, A.L. Holmes, and J.P. Wise, MUTAT RES-GEN TOX EN 610 , 2(2006).

2. N. Unceta, F. Séby, J. Malherbe, and O. F. X. Donard, Anal. Bioanal. Chem. 397, 1097 (2010).

3. M.B. Hansen, J.D. Johansen, and T. Menne, Contact Dermatitis 49, 206 (2003).

4. D.A. Eastmond, J.T. MacGregor, and R.S. Slesinski, Crit. Rev. Toxicol. 38, 173 (2008).

5. Y.W. Wu, Y.Y. Jiang, D.Y. Han, F. Wang, and J.X. Zhu, Microchim. Acta 159, 333 (2007).

6. Abayneh A. Ambushe, Robert I. McCrindle, and Cheryl M. E. McCrindle, J. Anal. At. Spectrom. 24, 502 (2009).

7. V. Gomez, and M.P. Callao, TRACTrends Anal. Chem. 25, 1006 (2006).

8. A.N. Tang, D.Q. Jiang, Y. Jiang, S.W. Wang, and X.P. Yan, J. Chromatogr. A 1036, 183 (2004).

9. H.N. Sedumedi, K.L. Mandiwana, and P. Ngobeni, J. Hazard. Mater. 172, 1686 (2009).

10. W. Cybulski, L. Jarosz, A. ChalabisMazurek, A. Jakubczak, K. Kostro, and K. Kursa, Pol. J. Vet. Sci. 12 , 339 (2009)
11. P. Wu, H. Chen, G.L. Cheng, and X.D. Hou, J. Anal. At. Spectrom. 24, 1098 (2009).

12. S.J. Dai, X.S. Zhang, L.Y. Yu, K. Xiao, L. Tong, D.M. Sun, and J. Tu, J SOC LEATH TECH CH 93, 245 (2009).

13. L. Leita, A. Margon, A. Pastrello, I. Arcon, M. Contin, and Mosetti D. Environ. Pollut. 157, 1862 (2009).

14. M. Grabarczyk, K. Tyszczuk, and M. Korolczuk, Electroanalysis 18, 1223 (2006).

15. B. Bas, Anal. Chim. Acta 570, 195 (2006).

16. A. Safavi, N. Maleki, and H.R. Shahbaazi, Talanta 68, 1113 (2006).

17. K.E. Levine, M.D. Stout, G.T. Ross, A.S. Essader, J.M. Perlmutter, P.M Grohse, R.A. Fernando, M. Lang, and B.J. Collins, Anal. Lett. 42 , 2729 (2009).

18. Y. Kurosaki, Y. Mizukami, N. Imamura, M. Yanagisawa, H. Hattori, and M. Hamaji, Bunseki Kagaku 58 827 (2009).

19. B.L. Batista, D. Grotto, J.L. Rodrigues, V.C.D. Souza, and F. Barbosa, Anal. Chim. Acta 64, 623 (2009).

20. S. D'Ilio, F. Petrucci, M. D'Amato, Gregorio M. Di, O. Senofonte, and N. Violante, Anal. Chim. Acta 624, 59 (2008).

21. N.N. Meeravali, and S.J. Jiang, Talanta 80, 173 (2009).

22. G.D. Matos, Reis E.B. dos, A.C.S Costa, and S.L.C. Ferreira, Microchem. J. 92, 135 (2009).

23. R.A. Kumbasar, J. Hazard. Mater. 167, 1141 (2009).

24. J.T. Liu, W.D. Zhang, Z.Q. Ren, and J.A. Ma, Ind. Eng. Chem. Res. 48, 4500 (2009).

25. P. Hemmatkhah, A. Bidari, S. Jafarvand, M.R.M. Hosseini, and Y. Assadi, Microchim. Acta 166, 69 (2009).

26. Z.H. Li, X.J. Chang, Z. Hu, X.P. Huang, X.J. Zou, Q. Wu, and R. Nie, J. Hazard. Mater. 166, 133 (2009).

27. A.A. Ambushe, R.I. McCrindle, and C.M.E. McCrindle, J. Anal. At. Spectrom. 24, 502 (2009).
28. O.D. Uluozlu, M. Tuzen, D. Mendil, B. Kahveci, and M. Soylak, J. Hazard. Mater. 172, 395 (2009).

29. O.D. Uluozlu, M. Tuzen, and M. Soylak, Toxicol 47, 2601 (2009).

30. S.K.Sahu, P. Meshram, B.D. Pandey, V. Kumar, and T.R. Mankhand, Hydrometallurgy 99, 170 (2009).

31. S. Kocaoba, and G. Akcin, Monatsh. Chem. 139, 873 (2008).

32. Y. Liu, P. Liang, and L. Guo, Talanta 68, 25 (2007).

33. O. Abollino, M. Aceto, C. Sarzanini, and E. Mentasti, Anal. Chim. Acta 411, 223 (2000).

34. J. Sabo Suleiman, B. Hu, H.Y. Peng, and C.Z. Huang, Talanta 77, 1579 (2009).

35. G. Howard Alan, J. Environ. Monit. 12, 135 (2010).

36. K. Bielicka-Daszkiewicz, and A.Voelkel, Talanta 80, 614 (2009).

37. Z.L. Lei, X.L. Pang, N. Li, L. Lin, and Y.L. Li, J. Mater. Process. Technol. 209, 3218 (2009)

38. X.L. Pu, Z.C. Jiang, B. Hu, and H.B. Wang, J. Anal. Atom. Spectrom 19, 984 (2004)

39. X.Q. Liu, Z.Y. Ma, J.M. Xing, and H.Z. Liu, J. Magn. Magn. Mater 270, 1 (2004).

40. O.D. Uluozlu, M. Tuzen, and D. Mendil, J. Hazard. Mater. 172, 395 (2009).

41. A .Karatepe, E . Korkmaz, and M. Soylak, J. Hazard. Mater. 173, 433 (2010).

42. L.L. Wang, J.Q. Wang, and Z.X. Zheng, J. Hazard. Mater. 177, 114 (2010).

43. H. Chen, P. Du, and J. Chen, Talanta 81, 176 (2010).

44. B.W. Morris, S. MacNeil, K. Stanley, and T.A. Gray, J. Endocrin. 139, 339 (1993).

45. B.W. Morris, S. MacNeiL, C.A. Hardisty, S. Heller, C. Burgin, and T.A. Gray, J. Trace Elem. Med. Biol. 13, 57 (1999) 